\title{
KOMUNIKASI KEPIMPINAN BERKESAN
}

\author{
Effective Communication for Leaders
}

\author{
Helmi Akhtar ${ }^{1}$ \\ Ilhaamie Abdul Ghani Azmi²
}

\begin{abstract}
Effective communication is essential for every leader. This is due to good communication can result in peace and harmony among followers or workers and is important for achieving objectives. Thus, this article focuses on effective leadership communication. A qualitative method was used whereby documents were examined for a clear understading of an Islamic form communication, the types of communication, and the principles and ethics behind said communication. Accordingly, this article will cover the definition and characteristics of effective communication from the Islamic perspective. Generally, this paper is different from previous articles in terms of its reliance on the thoughts of Imām alGhazāli regading the characterisctics of effective communication that should be practiced by leaders in the contemporary period.
\end{abstract}

Keywords: leadership, communication, effectiveness

1 Teacher, SMA Al-Asyraf, Bukit Merchat, Alor Gajah, 78000, Melaka, helmiakhtar@yahoo.com

2 Associate Profesor, Department of Shariah and Management, Academy of Islamic Studies, University of Malaya, 50603 Kuala Lumpur, ilhaamie@yahoo.com 


\section{PENGENALAN}

Komunikasi Islam merupakan salah satu bentuk interaksi manusia dalam kehidupan sosial, yang tidak terlepas dari dua sumber iaitu al-Quran dan alSunnah. Ini kerana proses komunikasi merupakan bahagian yang penting dalam muamalat, iaitu hubungan manusia sesama manusia yang lebih luas. Islam menghendaki nilai-nilai syar'ie ini dapat mewarnai dalam proses komunikasi sehingga melahirkan suatu kedudukan di mana komunikasi melahirkan suasana kedamaian bukan permusuhan. ${ }^{3}$ Ianya bersesuaian dengan ajaran Islam yang menganjurkan keharmonian di atas muka bumi. Oleh itu, Islam menganggap komunikasi sebagai satu wasilah yang penting yang menganjurkan perdamaian dalam kalangan umatnya sepanjang zaman.

Kepentingan komunikasi dari perspektif Islam boleh dilihat dari sudut menyebarkan dakwah, menjaga hubungan sesama manusia dan hubungan dengan Allah, melaksanakan tuntutan-tuntutan Syariah dan menegakkan prinsip amar ma'rūf nahī munkar serta melaksanakan apa sahaja perintah Allah dan menjauhi diri segala laranganNya. Bagi mencapai maksud yang difahami, Allah SWT telah menjelaskan kepentingan komunikasi dengan jelas dalam al-Quran seperti firmanNya:

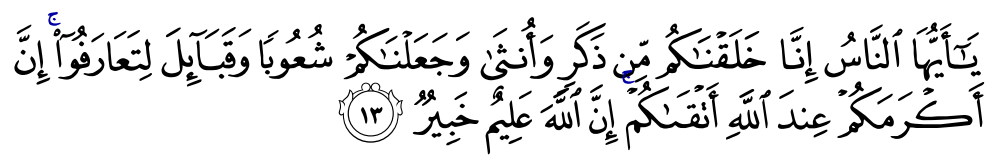

"Wahai umat manusia! Sesungguhnya Kami telah menjadikan dari kalangan lelaki dan wanita dan Kami telah menjadikan pelbagai bangsa dan puak, supaya kamu dapat saling berkenalan (dan dapat beramah mesra) Sesungguhnya semulia-mulia kamu di sisi Allah ialah yang paling bertaqwa (bukan yang lebih keturunan dan bangsa) Sesungguhnya Allah Maha Mengetahui lagi Maha Mendalam PengetahuanNya (hal keadaan kamu)",

(Surah al-Hujurāt, 49: 13)

Komunikasi yang berkesan adalah antara faktor utama kejayaan dalam sesebuah organisasi. Sejarah Islam telah menunjukkan bagaimana kejayaan dakwah Rasulullah SAW yang telah berkomunikasi dengan cemerlang, dan hasilnya seluruh semenanjung Tanah Arab telah dapat diIslamkan dengan jayanya. Melihat kepada latar belakang sikap, perangai, cara hidup dan budaya

\footnotetext{
Asep Dadan Wildan, Prinsip-Prinsip Komunikasi di dalam Islam: Tumpuan terhadap Surah al-Hujurat (Kuala Lumpur: Universiti Malaya, 2003), 33.
} 
bangsa Arab itu sendiri yang dianggap begitu kasar, pembengis serta biadap, adalah sukar bagi seseorang yang ingin berdakwah dan mengajak mereka melakukan perubahan sikap dan perangai mereka itu. Akan tetapi dengan kesabaran yang tinggi yang ada pada Rasulullah SAW dan cara berkomunikasi yang penuh dengan hikmah, maka cabaran yang begitu hebat dapat diatasi. Malah, perkembangan dakwah baginda SAW sendiri dianggap sebagai suatu revolusi komunikasi di zaman itu yang melampaui batasan geografi, bahasa dan bangsa. ${ }^{4}$ Utusan-utusan dakwah Nabi SAW telah berjaya menyampaikan mesej Islam kepada pemerintah Rom, Parsi, Mesir dan sebagainya. Penulisan artikel ini mengupas intipati karya-karya al-Imam al-Ghazālī yang membincangkan dan menghuraikan sifat-sifat sabar, jujur dan tabah yang memberikan kesan besar kepada peranan komunikasi ketika berdakwah.

\section{DEFINISI KOMUNIKASI}

Takrifan komunikasi adalah berbeza antara takrifan semasa dan pada masa lampau. Jikalau pada masa lampau, bidang komunikasi lebih tertumpu secara lisan sahaja manakala takrifan hari ini pula selari dengan kemajuan sains dan teknologi maklumat, komunikasi dilakukan melalui media seperti telefon, faksimili, internet, sidang video dan sebagainya. Lantaran persepsi yang berbeza itu, sudah tentu perselisihan pendapat di antara ahli teori komunikasi tidak dapat dielakkan untuk meletak dan menentukan takrifan komunikasi di bawah satu makna sahaja.

Carl I. Hovland menyatakan komunikasi ialah proses di mana seorang penutur memindahkan rangsangan (biasanya perlambangan berbentuk katakata) untuk mengubah tingkah laku orang lain. Daripada definisi ini, terdapat satu faktor yang jelas berhubung kait dengan kepimpinan iaitu tujuan. Komunikasi yang digunakan bukan setakat untuk menyampaikan pesanan tetapi ia melibatkan satu tujuan yang lebih bermakna iaitu merubah tingkah laku orang lain dan merangsang tindakan yang positif.

\section{ISTILAH KOMUNIKASI}

Adapun istilah-istilah komunikasi dalam al-Quran terbahagi kepada dua jenis: ${ }^{5}$

\footnotetext{
4 Muhammad Sa 'īd Ramaḍān al-Būṭị, Sìrah al-Nabawiyyah (Sūriyyah: Dār al-Fikr, 1991), 33 .

5 Asep Dadan Wildan, Prinsip-Prinsip Komunikasi di dalam Islam: Tumpuan terhadap Surah al-Hujurat, 34-51.
} 


\section{Komunikasi Lisan (Verbal)}

Ianya terbahagi kepada qawlan (perkataan). Dalam al-Quran, terdapat berbagai bentuk perkataan yang diistilahkan dengan perkataan qawlan seperti di bawah ini:

\section{a) Qawlan Sadīan (Perkataan yang Benar)}

Beberapa tafsiran kepada maksud qawlan sadīdan antaranya bermaksud adil dan benar. ${ }^{6}$ Manakala Ibn Kathīr memberikan maksud perkataan yang lurus dan tidak berpaling dari perjanjian. ${ }^{7}$

\section{ii. Qawlan Balīghan (Perkataan yang berkesan)}

Mengikut Abū Ja'far Muḥammad bin al-Ḥasan, ianya memberi maksud perkataan yang fasih yang dapat menejelaskan berita yang sesuai dengan hati pendengar (komunikasi). Kaedah ini akan memberi kesan kepada jiwa mereka. ${ }^{8}$

\section{iii. Qawlan Maysūran (Perkataan yang menyenangkan hati)}

Mengikut pendapat Imam Ibn Kathīr, ianya memberi maksud berbicara dengan cara yang lemah lembut dan mudah difahami. Dalam proses komunikasi, agar sesuatu maklumat dapat difahami, ianya hendaklah menggunakan perkataan yang umum dan mudah supaya dapat mengelakkan ianya tidak difahami apabila berkomunikasi secara lisan. ${ }^{9}$

\section{Komunikasi bukan lisan (non-verbal)}

Komunikasi bukan lisan boleh dianggap sebagai media utama komunikasi yang paling efektif. Ini disebabkan pengaruh bukan lisan seperti pergerakan badan, perawakan muka, pergerakan mata dan sentuhan mudah bertindak balas

$6 \quad$ Ahmad Muștafā al-Marāghī, Tafsīr al-Marāghī, vol. 4 (Bayrūt: Dār Ihyā' al-Turāth al-'Arab, 1974), 191.

7 Abī Fidā' Ismā'il bin Kathīr al-Qurayshī al-Dimashq, Tafsīr al-Qur'ān al- 'Azìm, vol. 3 (Beirūt: Dār al-Andalus, 1984), 522.

8 Asep Dadan Wildan, Prinsip-Prinsip Komunikasi di dalam Islam: Tumpuan terhadap Surah al-Hujurat, 42.

9 Asep Dadan Wildan, Prinsip-Prinsip Komunikasi di dalam Islam: Tumpuan terhadap Surah al-Hujurat, 49. 
berbanding dengan komuniksi secara lisan. Selain dari itu, komunikasi tanpa lisan boleh dianggap lebih jujur dalam menerangkan sejauhmana kebenaran atau keikhlasan yang dipertuturkan.

\section{JENIS-JENIS KOMUNIKASI ${ }^{10}$}

Ahli-ahli komunikasi Islam telah membahagikan jenis-jenis komunikasi kepada tiga bahagian, iaitu:

\section{Komunikasi dengan Allah}

Ia merupakan tingkatan komunikasi yang tertinggi kerana berkait rapat dengan hubungan Allah SWT semasa beribadat. Tiadalah ${ }^{11}$ sesuatu ibadat yang dianggap rapat dengan Allah SWT melain ketika solat iaitu semasa sujudnya. Malah, keistimewaan dalam Islam, ia tidak menghadkan tempat, ruang serta masa untuk beribadat. Keupayaan umat Islam untuk beribadat merupakan suatu perkara yang amat diberikan penekanan oleh syariat Islam.

\section{Komunikasi sesama Manusia}

Ianya lebih menekankan komunikasi secara bersemuka atau bersifat dua hala seperti komunikasi melalui alat perhubungan seperti telefon, internet perbincangan, taklimat, ceramah dan sebagainya. Dalam konteks ini, Islam mengiktiraf dan menerima segala bentuk komunikasi selagi ianya tidak memberi kesan negatif terhadap keaslian fitrah manusia yang memerlukan keamanan, kebaikan dan lain-lainya. Komunikasi peringkat ini tidak terbatas kepada sesama manusia sahaja, malah al-Quran menceritakan bagaimana Nabi Sulaiman diberikan kelebihan untuk memahami pertuturan burung dan semut.

\section{Komunikasi dengan Diri Sendiri}

Ia berbentuk lebih kepada penilaian terhadap amalan-amalan (muhasabah diri) dan melibatkan unsur-unsur niat dan berfikir, malah dalam Islam sendiri, masalah niat itu penting kerana akan menentukan sah atau tidak sahnya sesuatu perbuatan khasnya ibadat. Malah, peranan niat dalam konteks undang-undang

10 Asep Dadan Wildan, Prinsip-Prinsip Komunikasi di dalam Islam: Tumpuan terhadap Surah al-Hujurat, 113-128.

11 Saodah Wok, Teori-Teori Komunikasi (Kuala Lumpur: PTS Publishing Sdn Bhd, 2006), 216. 
disebut motif menjadi perkara yang amat penting dalam perlaksanaan undangundang bagi memastikan seseorang itu bersalah atau tidak.

Manakala jenis-jenis komunikasi berdasarkan ilmu komunikasi terbahagi kepada dua jenis sahaja iaitu:

i. Komunikasi lisan, iaitu proses yang melibatkan lisan yang menitik beratkan keadaan nada suara, bahasa yang digunakan, kefasihan sebutan dan kelancaran perkataan yang digunakan. Komunikasi cara ini hendaklah sejajar dengan pergerakkan anggota badan, memek muka dan gerak mata. Contoh komunikasi lisan seperti ini boleh dilihat di telefon, perkhidmatan kaunter, ceramah, taklimat, mesyuarat, bengkel dan persidangan.

ii. Komunikasi bukan lisan, iaitu komunikasi yang tidak melibatkan suara. Prosesnya adalah secara bertulis, bercetak ataupun melalui penggunaan isyarat, simbol dan pergerakkan lain-lain anggota badan. Komunikasi jenis ini lebih mudah mudah difahami makna mesej yang disampaikan terutama yang menggunakan anggota badan seperti tangan, badan, kontek mata dan memek atau air muka. Sehubungan dengan ini, komunikasi jarak, komunikasi melalui pakaian, melalui bau dan lain-lain lagi juga memberi kesan dalam perhubungan dengan masyarakat sekeliling terutamanya dalam organisasi.

\section{PRINSIP KOMUNIKASI ISLAM}

Prinsip-prinsip dan kaedah-kaedah yang diutarakan dalam Islam sememangnya mudah untuk dilaksanakan berdasarkan kepada keupayaan seseorang. Antaranya ialah:

a) Memulakan percakapan dengan ucapan salam "Assalamualaikum". Ini berdasarkan kepada hadis Nabi SAW, yang diriwayatkan oleh Jabir bin 'Abd Allāh:

$$
\text { "Ucapan salam sebelum membuat ucapan... " }
$$

Maksud salam sendiri itu bermaksud sejahtera dan aman. Malah, Islam menjadikan kesejahteraan dan keamanan sebagai suatu yang menjadi keperluan penting manusia sejagat. Tanpa jaminan keamanan dan kesejahteraan, perhubungan dan komunikasi antara manusia akan terjejas juga. Dasar Islam sendiri yang menjadi rahmat untuk sekalian alam inilah menjadi asas yang

12 Muhammad bin 'Isa al-Tirmidhī, Jāmi' al-Tirmidhī (Bayrūt: Dār al-Gharb alIslāmī, 1998), no. hadis 2643. 
sangat penting untuk memastikan kesejahteraan dapat dinikmati oleh semua makhluk.

b) Bercakap dengan lemah lembut. Nabi SAW sebagai teladan kepada umatnya telah menunjukkan sikap dan cara semasa berdepan dengan manusia untuk berdakwah. Firman Allah SWT:

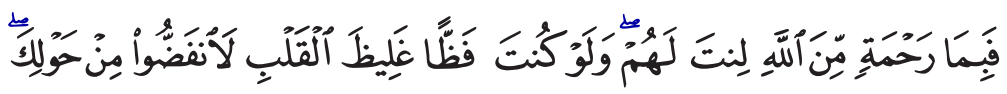

"Dengan sebab rahmat (yang melimpah-limpah) daripada Allah kamu telah berlemah-lembut. Kalaulah kamu bersikap kasar lagi keras, sudah pasti mereka akan menjauhkan diri dari kamu...

(Surah Āli-'Imrān, 3: 159)

Malah kepada musuh-musuh Islam sendiri diminta kita berdakwah dengan cara yang baik dan sopan seperti dalam firman Allah SWT:

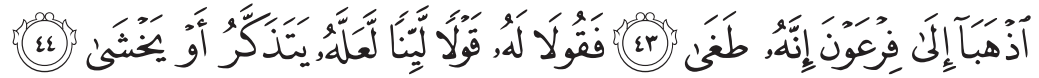

"Pergi kamu berdua (nabi Musa dan nabi Harun) kepada Firaun sesungguhnya ianya telah melampaui batas. Maka berkatalah kamu kepada nya dengan kata-kata yang baik semoga dia akan mengingati atau merasa takut..."

(Surah Ṭaha, 20: 43-44)

c) Menggunakan perkataan yang baik. Cara berdakwah yang baik dengan menggunakan kata-kata yang tidak menyinggung perasaan manusia juga diberikan penekanan dalam Islam sendiri. Firman Allah SWT:

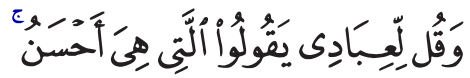

"Dan katakanlah (wahai Muhammad) kepada hamba-hambaku yang beriman supaya mereka menggunakan perkataan-perkataan yang baik-baik..."

(Surah al-Isrā', 17: 53)

d) Menyesuaikan bahasa dan isi percakapan mengikut tingkatan kecerdasan pendengar. Setiap manusia mempunyai kemampuan berfikir yang berbeza antara satu sama lain. Oleh itu, seorang pemimpin yang berkesan mestilah meraikan kemampuan semasa berkomunikasi. Ini berdasarkan kepada hadis Nabi SAW yang diriwayatkan oleh 'Abd Allāh bin 'Abbās berkata: 


$$
\text { أمرنا أن نكلّم النّاس على قدر عقولهم }
$$

"Kami diperintahkan untuk berbicara dengan manusia mengikut kemampuan akal mereka..." 13

e) Menyebut perkara-perkara penting berulang-ulang kali. Adalah menjadi amalan nabi SAW akan mengulang-ulangkan sesuatu perkara yang penting sehinggalah ianya difahami oleh pendengarnya. Hikmah pengulangan mesej adalah perlu sebagai suatu peringatan kepada si pendengar bahawa ianya merupakan perkara yang penting dan perlu diberikan perhatian yang serius.

\section{ETIKA KOMUNIKASI MENURUT ISLAM}

Etika bermaksud sebahagian atau cabang ilmu falsafah yang menentukan bentuk tingkah laku yang betul. Fungsi etika ialah ianya menjadi asas dan kayu pengukur tingkahlaku yang betul dan tidak betul. Menurut pandangan Islam pula, etika ini didefinisikan sebagai akhlak. Akhlak ini berasal dari perkataan khuluq yang terdapat dalam al-Quran:

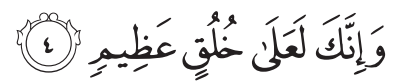

"Sesungguhnya kamu wahai Muhammad mempunyai perilaku akhlak yang amat baik...”

(Surah al-Qalam, 68: 4)

Sementara itu, akhlak dalam Islam mempunyai pengertian yang tersendiri iaitu suatu ilmu yang menerangkan sifat-sifat kebaikan dan cara-cara untuk mendapatkannya. Ia juga menerangkan sifat-sifat keburukan dan cara-cara menjaga diri dari terjebak melakukannya. Dalam Islam, antara faktor-faktor kepimpinan yang cemerlang ialah faktor-faktor yang berkaitan akhlak dan tingkahlaku yang selaras dengan roh dan syariat Islam serta falsafah Islam. Apa yang lebih difahami bukan setakat ciri-ciri kepimpinan bahkan setakat mana dapat seseorang pemimpin itu dapat mencirikan kepimpinannya dengan ciri-ciri kualiti akhlak. Walaupun terdapat persamaan antara etika Islam dan barat tetapi ia berbeza dari sudut sumber. Etika Islam bersumberkan dari alQuran dan hadis. Manakala etika barat bersumberkan teori akal yang diambil

13 al-Sakhawī, al-Maqāṣid al-Hasanah fì ma Ashtahar 'ala al-Alsinah, vol. 1 (Bayrūt: Dār al-Kitāb al-'Arab̄̄, 1985), no. hadis 177. 
dari pemikiran ahli falsafah barat yang sudah tentunya terpengaruh kepada kehendak hawa nafsu semata-mata tanpa ada sandaran dan rujukan yang kuat. ${ }^{14}$

\section{KEPIMPINAN ISLAM}

Kepimpinan ialah satu seni yang menyusun antara individu dengan beberapa kumpulan untuk membentuk interaksi antara manusia untuk mencapai matlamat tertentu. ${ }^{15}$ Dalam usaha untuk mencapai kualiti kepimpinan amatlah perlu kemahiran berkomunikasi diberikan peranan penting untuk menghuraikan kehendak visi dan misi supaya menjadi lebih jelas landasan yang akan diikuti. Oleh kerana kepimpinan melibatkan proses memimpin, membimbing, mempengaruhi atau menguasai pemikiran, maka komunikasi penting dalam mewujudkan suatu hubungan berbentuk komunikatif. ${ }^{16}$ Kegagalan sesebuah organisasi dalam mencapai visi dan misi mereka kerana kegagalan kumpulan pengurusan tertinggi menyampaikan hasrat dan kehendak visi dan misi kepada kumpulan pelaksana. Kemampuan kumpulan tertinggi berkomunikasi dengan kumpulan pelaksana akan menjadi kayu pengukur kejayaan organisasi tersebut.

Islam telah menentukan beberapa syarat-syarat yang akan mengesahkan kepimpinan seseorang. Antara syarat-syarat itu ialah:

i) Membanyakkan sifat mahmudah seperti berilmu, adil, berani, kesucian moral, pemurah, pemaaf, bertimbang rasa, menepati janji, benar, tegas, bijaksana cekap berfikir dan sebagainya. Apabila pemimpin yang mempunyai sifat-sifat mahmudah ini, beliau merupakan seorang pemimpin yang berintergriti tidak mudah menerima sogokan, rasuah dan ada daya kepimpinan yang boleh diteladani subordinat yang berada di bawah kepimpinannya. ${ }^{17}$

ii) Memelihara hubungan baik dengan tuhan sebagaimana firman Allah SWT:

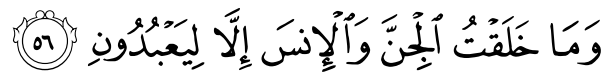

"Tidak aku jadikan manusia kecuali untuk beribadat kepada Aku..”

14 Saodah Wok, Teori-Teori Komunikasi (Kuala Lumpur: PTS Publishing Sdn. Bhd., 2006), 190.

15 Kamaruzzaman Noordin, Komunikasi Kepimpinan Menurut Islam dalam Dimensi Pengurusan Islam (Kuala Lumpur: Penerbit Universiti Malaya, 2006), 140.

16 Onong Uchana Effendy MA, Kepimpinan dan Komunikasi (Bandung: Penerbit Alumni, 1981), 39.

17 al-Mawardī, al-Aḥkām al-Sulțāniyyah (Beirūt: Dār al-Kutub 'Ilmiyyah, 1985), 6. 
(Surah al-Dhāriyāt, 51: 56)

Perlu dingat hubungan dengan manusia tidak sempurna sekiranya tidak menjaga hubungan dengan Allah sebaik mungkin. Adalah menjadi kewajipan untuk mendahulukan hubungan dengan Allah SWT berbanding hubungan dengan manusia. Apabila kita berusaha menjaga hak-hak Allah SWT dengan sebaiknya ada jaminan di mana Allah SWT akan menjaga hak-hak manusia.

iii. Memelihara hubungan baik sesama manusia bersesuaian dengan firman Allah SWT yang berbunyi:

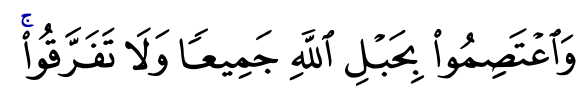

"Dan berpegang teguhlah kamu semua kepada tali Allah dan jangan sesekali kamu bercerai berai ".

(Surah Āli-'Imrān, 3: 103)

Tali Allah SWT yang dimaksudkan ialah Kitab Allah iaitu al-Quran yang mengandungi arahan-arahan dan perintah untuk menjaga perhubungan sesama manusia. Masyarakat yang sejahtera terdiri daripada individu-individu yang memahami tanggungjawab sosial dan senantiasa mangambil tahu perkaraperkara dan bersifat cakna kepada yang berlaku di sekeliling mereka. Adalah bertepatan di mana Allah SWT menggunakan kalimah "habl" yang bermaksud tali seperti yang difahami dalam penggunaan biasa adalah untuk menyelamatkan manusia dari tenggelam dan lemas di dasar laut. Manakala al-Quran juga mempunyai peranan yang amat besar sebagai mana tali iaitu menyelamatkan manusia dari kesesatan hidup dalam dunia. Jadi, penggunaan tali dalam ayat ini adalah untuk memudahkan manusia memahami dengan lebih jelas.

iv. Memelihara hubungan baik dengan alam persekitaran yang terdiri daripada tumbuh-tumbuhan dan binatang-binatang. Ini bertepatan dengan risalah Nabi SAW sebagai rahmat untuk sekelian alam, maksud alam itu sendiri ialah selain dari Allah SWT. Firman Allah SWT:

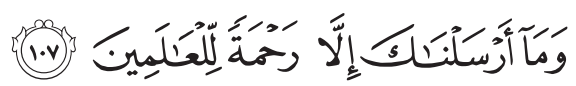

"Tidak Kami utuskan (wahai Muhammad) kecuali sebagai rahmat (kasihan belas) terhadap alam ini."

(Surah al-Anbiyā', 21: 107)

Hubungan yang baik dengan alam sekitar perlu untuk menjamin kesejahteraan alam berterusan. Manusia tidak mungkin boleh menjalani kehidupan normal tanpa ada unsur-unsur persekitaran seperti tumbuhan dan 
haiwan. Manusia dengan tugas sebagai khalifah unggul sudah tentu tidak akan lengkap tanpa mempunyai komunikasi yang berkesan.

\section{PERANAN PEMIMPIN DALAM KOMUNIKASI}

Seorang yang menjadi pemimpin seharus menyedari keperluannya menguasai teknik berkomunikasi yang berkesan. Kegagalannya menguasai komunikasi yang berkesan akan menyebabkan sistem penyampaian maklumat kepada subordinat kurang difahami atau mungkin menjadi khilaf antara mereka dan ini akan memberi kesan yang besar kepada perjalanan organisasi. Oleh itu, sebagai seorang pengurus mestilah mempunyai kewibawaan, kemampuan mengurus, dan memimpin yang unggul, di samping daya motivasi yang tinggi untuk diteladani oleh anggota organisasi yang lain. Bernard berpendapat satusatu arahan dianggap berwibawa apabila memenuhi empat syarat berikut: ${ }^{18}$

a) Pegawai rendah berkebolehan dan berkemampuan untuk mengerti cara arahan yang dikomunikasikan.

b) Ketika membuat keputusan, dia mempercayai arahan itu selari dengan tujuan organisasi.

c) Ketika membuat keputusan dipercayai arahannya sepadan dengan secara keseluruhan.

d) Ianya secara mental dan fizikal berkebolehan untuk melaksanakan arahan itu.

Pengurusan atasan hendaklah memastikan proses penyampaian maklumat yang sesuai diwujudkan dalam organisasi dan keberkesanan sistem pengurusan kualiti disampaikan kepada semua anggota organisasi. Pihak pengurusan atasan juga haruslah memastikan, wujudnya forum yang sesuai bagi anggotaanggota organisasi berkomunikasi berhubung dengan perkara-perkara atau isu-isu yang berkaitan dengan keberkesanan sistem pengurusan kualiti. Ini boleh dilakukan misalnya melalui mesyuarat, sistem peti cadangan dialog, taklimat, pengiktirafan di atas pencapaian, papan kenyataan, in-house jurnal, media audio-visual, media elektronik dan sebagainya.

Menurut Carl. I.Hovland menjelaskan bahawa tujuan berkomunikasi yang terpenting ialah untuk mengubahkan tingkah laku orang lain. ${ }^{19}$ Peranan

18 Raja Roslan Raja Abd. Rahman, Azizi Yahya \& Mohd. Salleh Hassan, 'Peranan Komunikasi Kepimpinan Diri dan Organisasi dalam Perspektif Islam,' (Seminar Kebangsaan Kemahiran Insaniah dan Kesejahteraan Sosial, Mahkota Hotel Melaka, 18-19 Ogos 2008), 8.

19 Onong Uchana Effendy MA, Kepimpinan dan Komunikasi, 39. 
pemimpin dalam komunikasi boleh dibahagikan kepada beberapa bahagian iaitu: ${ }^{20}$

\section{Pemimpin sebagai Penyebar Maklumat}

Seorang pemimpin bertindak sebagai pemimpin yang menyampaikan idea, fakta dan menerangkan rasional setiap cadangan dan arahan kepada seluruh anggota organisasi, di samping berperanan sebagai penyampai maklumat dari dunia luar yang bermanfaat kepada organisasinya. Seorang pemimpin akan menjadi jurucakap organisasinya dalam segala hal yang berkaitan pihakpihak yang berkepentingan di luar. Untuk memudahkan ia menjalankan tugas-tugasnya, seorang pemimpin mempunyai faktor daya tarik (source attractiveness) dan kepercayaan (credibility) yang akan menghilangkan unsurunsur keraguan agar maklumat yang disampaikan akan benar-benar difahami.

\section{Pemimpin sebagai Perunding}

Ini bermakna seorang pemimpin menjadi jurucakap dalam organisasi untuk mencari penyelesaian masalah yang dihadapi dengan menggunakan mekanisme komunikasi. Ini bermakna seorang pemimpin perlu peka dengan memiliki hubungan interpersonal untuk mencari maklumat secepat mungkin dari laporan-laporan dalam bentuk laporan bertulis atau dapatan-dapatan yang telah dirumuskan. ${ }^{21}$ Dengan menggunakan kemahiran berkomunikasi, mereka menggunakan gaya pujukan dan dapat memberi alasan kepada diri sendiri atau pihak lain supaya dapat menerima sesuatu penyelesaian atau kedudukannya. ${ }^{22}$

\section{Pemimpin sebagai Pemantau}

Seorang pemimpin haruslah melakukan pemantauan dan pemerhatian bagi meneliti setiap gejala yang wujud yang ada di persekitaran yang mungkin menimbulkan pengaruh kepada diri, kelompok dan organisasi. Dalam situasi ini, seorang pemimpin bertindak menerima pesanan kerana ianya merupakan proses penerimaan maklumat yang berterusan. Tugas pemantau memerlukan

20 Kamaruzzaman Noordin, Komunikasi Kepimpinan Menurut Islam dalam Dimensi Pengurusan Islam, 141.

21 Muhd Mansur Abdullah, Komunikasi dalam Pengurusan (Kuala Lumpur: Dewan Bahasa dan Pustaka, 2002), 144.

22 Abdul Mua'ti Zamri Ahmad, Santun Komunikasi (Kuala Lumpur: Dewan Bahasa dan Pustaka, 2001), 74. 
pemimpin yang banyak berkomunikasi untuk mendapatkan maklum balas dan juga pandangan umum mengenai organisasi. Segala maklum balas ini penting untuk tujuan penambahbaikan atas kegagalan atau respon negatif samada dari dalam organisasi atau luar. Hasil daripada pemantauan dapat digunakan untuk mengurangkan maklum balas negatif.

\section{Pemimpin sebagai Penghubung}

Seorang pemimpin bertindak sebagai penghubung antara sub-unitnya dengan sub-unit lain yang terdapat dalam organisasi. Selain itu, ia juga berperanan sebagai penyambung idea di samping perlu menyatakan idea lama dalam bentuk yang lebih murni. Peranan yang lebih besar lagi, seorang pemimpin hendaklah lebih berpengaruh, mengawal pengaliran maklumat dan bertindak sebagai pengintergrasi kumpulan dan individu.

\section{Pemimpin sebagai Agen Perubahan}

Kepimpinan yang berkesan ialah kepimpinan yang dapat mempengaruhi perubahan dan tingkah laku ke arah perubahan yang positif. Untuk tujuan itu, seorang pemimpin sewajarnya mempunyai kelayakan yang sesuai, berpengalaman dan kreatif, dapat menyesuaikan diri dengan situasi dan dapat bertindak dengan lebih rasional. Lantaran itu, pengalaman, sikap dan nilai yang ada pada diri pemimpin amat berkesan untuk mempengaruhi tindakan-tindakan orang bawahannya. Kepercayaan dan kredibiliti merupakan kelayakan yang paling tidak boleh diketepikan bagi tujuan melaksanakan pujukan. Corak komunikasi dalam kepimpinan boleh mempengaruhi ahli-ahli organisasi menjangka dan menerima sebarang perubahan dengan memberi pernyataan yang jelas tentang segala aspek berhubung program-program perubahan, rancangan dan harapan pemimpin itu sendiri.

\section{KOMUNIKASI KEPIMPINAN MENURUT ISLAM}

Komunikasi kepimpinan mengikut tafsiran moden boleh didefinisikan sebagai gaya, kaedah dan strategi komunikasi yang digunakan semasa menjalankan peranan dan tugas formal pemimpin dalam organisasi. Ia merupakan proses untuk mencipta dan bertukar-tukar mesej dalam rangkaian hubungan yang saling bergantung antara satu sama lain untuk menyelesaikan perkara-perkara yang berlaku. 
Komunikasi kepimpinan mengikut Mohd Yusuf Hussain ${ }^{23}$ boleh dikatakan sebagai gaya, kaedah, dan strategi komunikasi yang digunakan oleh pemimpin semasa menjalankan peranan dan tugas formal pemimpin dalam sesebuah organisasi. Tugas formal tersebut termasuklah memberi arahan, taklimat dan penjelasan memberikan tunjuk ajar, teguran dan nasihat, mempengerusikan mesyuarat, menyelia, menyelaras, mendapatkan maklumat dan sebagainya.

Komunikasi kepimpinan merujuk kepada contoh dan teladan yang sewajarnya ditunjukkan oleh seorang pemimpin bukan sahaja tentang gaya, kaedah dan strategi komunikasi bahkan meliputi aspek akhlak dan amal ibadat. Menurut kaedah kepimpinan Islam, seseorang pemimpin yang mempunyai kemahiran berkomunikasi yang baik akan tetapi kurang dan tidak menjaga bidang akhlak dan amal salih, tidak boleh dianggap sebagai pemimpin yang baik. Ini kerana Islam menjadikan bidang kepimpinan sebagai satu ibadat yang sama penting dengan ibadat khusus yang lain seperti puasa, solat dan sebagainya. Tugas seorang pemimpin tidak hanya terbatas kepada usahausaha menyampaikan mesej semata-mata akan tetapi harus peka kepada kesan langsung komunikasinya terhadap orang yang dipimpinnya. Bahkan kewibawaanya banyak terletak kepada integrasinya terhadap reaksinya serta cara memberikan layanan kepada anggota bawahannya.

Komunikasi kepimpinan diperlukan sebagai jaminan agar semua proses berjalan dengan baik. Di samping itu, ianya juga diperlukan untuk membolehkan proses timbal balik menerusi individu dari pelbagai sumber, seterusnya menjadi pemangkin kepada hubungan kemanusiaan yang lebih mesra antara pemimpin dan orang yang dipimpin. Kesan positif yang diperolehi dari proses itu ialah segala unsur-unsur kelemahan dan kekurangan boleh dinilai semula untuk meningkatkan produktiviti dan kepuasan kerja dalam kalangan anggota organisasi sekaligus mengurangkan ketidakhadiran, rungutan dan sabotaj yang banyak berpunca lantaran komunikasi kepimpinan yang kurang berkesan.

Pemimpin organisasi yang berjaya sewajarnya seorang yang boleh berkomunikasi dengan orang bawahannya dengan berkesan untuk memastikan segala arahan dan taklimat dapat difahami dengan jelas tanpa menimbulkan sebarang tanda tanya dan kekeliruan dalam kalangan mereka.

\section{PRINSIP KOMUNIKASI PEMIMPIN MENURUT ISLAM}

Islam sebagai satu cara yang cukup sempurna telah menetapkan prinsip-prinsip yang harus diikuti oleh setiap pemimpin semasa berinteraksi dan berkomunikasi

23 Mohd Yusuf Hussain, 'Komunikasi Kepimpinan Menurut Perpekstif Islam,' dalam Kecemerlangan Pentadbiran dan Amalan dalam Islam, ed. Shafie. Mohd Salleh et al. (Kuala Lumpur: Institut Tadbiran Awam Negara, 1990), 116. 
dengan orang bawahannya dan organisasi di bawah kepimpinannya. Jatuh bangun sesebuah organisasi bergantung kepada kepimpinannya. Di antara ciri-ciri kepimpinan yang baik ialah kemahiran komunikasi. Kemahiran berkomunikasi yang berkesan amat perlu dikuasai oleh setiap pemimpin untuk mempengaruhi tindakan-tindakan ahli-ahli organisasi di bawahnya selagi ianya tidak bercanggah dengan kehendak syariat. Antara prinsip komunikasi yang paling penting ialah hikmah.

Hikmah bermaksud setiap pendekatan dan tindakan hendaklah berdasarkan hikmah dan kasih sayang dan ianya sepatut mendasari setiap prinsip human oriented yang meletakkan penghargaan kepada manusia sebagai sebaik-baik ciptaan. Ini bertepatan dengan firman Allah SWT:

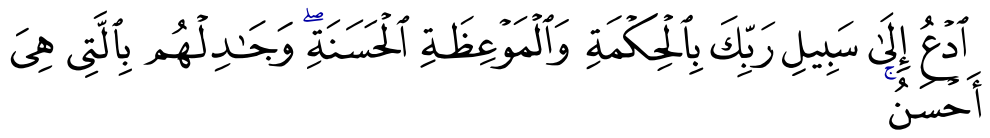

"Serulah kamu (wahai Muhammad) ke arah jalan Tuhan mu dengan penuh hikmah dan berdebatlah dengan cara-cara yang paling baik."

(Surah al-Naḥl, 16: 125)

Hikmah itu sendiri mengikut kamus dewan bermaksud kepandaian dan bijaksana. ${ }^{24}$ Tokoh-tokoh terkemuka bahasa telah mentafsirkan maksud hikmah sebagai usaha atau perkataan yang tepat dan bersesuaian dengan sasaran. Ianya juga bermaksud kebijaksanaan yang memerlukan seseorang itu arif dalam semua bidang ilmu pengetahuan, baik ilmu agama, mahupun ilmu akedemik seperti psikologi, sosiologi dan sebagainya. ${ }^{25}$

Wahbah al-Zuhaylī telah mendefinisikan hikmah sebagai perkataan yang jelas dengan dalil yang terang yang akan dapat menyampaikan kebenaran dan menyingkap keraguan. Seorang pemimpin mestilah bijak untuk memerhatikan suasana, situasi dan keadaan mereka yang di bawah kepimpinannya. Di samping itu, ianya juga hendaklah menggunakan cara yang relevan dan bersesuaian dengan kadar pemikiran, intelektual, psikologi dan juga sosial orang tersebut. Ini menyebabkan mereka tidak keberatan dengan metode dan penyampaian yang sesuai dengan keadaan. Ini juga berkait rapat dengan cara berbicara di samping mempelbagaikan cara penyampaian bersesuaian dengan

24 Kamus Dewan, edisi ke-3 (Kuala Lumpur: Dewan Bahasa dan Pustaka, 1996), 457.

25 Ghazzali Darusalam, Dinamika Ilmu Dakwah Islamiah (Kuala Lumpur: Utusan Publication, 1996), 28. 
keadaan dan tidak menyulitkan dengan tugasan-tugasan yang tidak bersedia untuk diterima oleh subordinat.

Dalam kemahiran berkomunikasi, hikmah merupakan pendekatan terhadap pihak komunikan sehingga apa yang dilakukan pihak komunikan timbul atas kesedaran sendiri tanpa dipaksa dan rasa tertekan. Inilah yang disebut sebagai frame of reference dan field of experience iaitu situasi total yang mempengaruhi sikap dari pihak komunikan. Ianya dibina atas dasar pendekatan persuasif (memujuk) dan sangat sesuai ditujukan kepada golongan cendekiawan dan ilmuan. Dalam sirah Nabi SAW diceritakan bagaimana Baginda SAW telah berdakwah kepada golongan cendekiawan Quraish yang diwakili oleh Husayn yang telah berdialog dengan Nabi SAW dalam mencari erti ketuhanan yang sebenar. Dakwaan beliau bahawa tuhan yang mereka sembah adalah banyak telah disanggah oleh Nabi SAW dengan cara yang lembut dengan menegaskan Tuhan yang di langit dan di bumi adalah tuhan yang sama sahaja bukan yang berlainan. Akhirnya, beliau telah menerima tawaran Nabi SAW untuk memeluk Islam setelah berpuas hati dengan jawapan yang diberikan.

Baginda Rasulullah SAW telah mengamalkan prinsip komunikasi yang telah diikuti oleh para sahabat semasa menyampaikan risalah dakwah. Amalan ini telah dijadikan teras dan asas dalam pengurusan pentadbiran Islam sehingga terbukti berkesan kepada komunikator dan komunikan. Dapat dilihat kejayaan nabi Muhammad SAW mempengaruhi dan menguasai masyarakat Badawi meskipun mereka itu dikenali kaum yang bersikap kasar bengis dan biadab. Amalan prinsip dapat ini mempengaruhi tingkahlaku pekerja dalam sesebuah organisasi. ${ }^{26}$ Antaranya ialah:

i. Bercakap dengan lemah lembut. Sebagai seorang pentadbir dan pengurus, komunikasi yang dilakukan hendaklah secara lembut dan ada ketegasan. Prinsip ini penting agar kakitangan yang menerima arahan dapat menerima dengan baik.

ii. Menggunakan perkataan yang baik-baik. Pentadbir dan pengurus sewajar mempunyai kata-kata kunci yang mudah untuk difahami. Adalah lebih baik sekiranya kata-kata yang digunakan berbentuk ringkas, padat tetapi mudah untuk difahami

iii. Menggunakan hikmah dan nasihat yang baik. Pendekatan nasihat adalah yang terbaik berbanding metod komunikasi pengurusan yang lain atas dasar manusia adalah sebaik-sebaik kejadian yang mempunyai akal yang lebih

26 Mohd Yusuf Husin, Kecemerlangan Pentadbiran Dasar dan Amalan dalam Islam (Kuala Lumpur: Institut Tadbiran Awam Negara, 1991), 1119. 
sempurna di samping emosi yang mudah menerima sentuhan berbanding makhluk-makhluk yang lain.

iv. Menyesuaikan bahasa dan isi percakapan dengan tahap kecerdasan akal dan pandangan pendengar. Seorang pentadbir yang cekap akan menggunakan seluruh kebolehan untuk memahami dan membaca kemampuan si pendengar (kakitangan) sebelum memberikan pandangan atau arahan kepadanya

v. Berbahas dengan cara yang lebih baik. Sekiranya berlaku salah faham dan ada perbahasan, maka pendekatan bahas yang terbaik digunakan, di samping meraikan pandangan-pandangan yang mungkin bertentangan dengan pendapatnya sendiri.

vi. Menyebut perkara yang penting berulang-ulang kali. Seorang pentadbir cekap akan senantiasa mengulang-ulang agar mesej yang disampaikan akan mudah diingati dan tidak menimbulkan kekeliruan yang lain pula.

vii. Mengotakan apa yang dikatakan. Sifat ini akan melambangkan kejujuran pentadbir itu. Kesan kepada kakitangan pula, mereka dapat menilai sikap tegas yang ada pengurus mereka dan akan melakukan kerja dan tugasan dengan penuh kejujuran sebagaimana pengurus mereka.

\section{RUKUN-RUKUN KOMUNIKASI ISLAM BAGI PEMIMPIN}

Untuk menghasilkan sesuatu komunikasi yang berkesan, ianya perlu melalui proses-proses yang akan akan menjamin kelancaran komunikasi itu sendiri. Antara rukun-rukun komunikasi yang penting ialah:

\section{Merancang Idea sebelum Berkomunikasi}

Sebagai seorang pemimpin sebuah organisasi adalah sesuatu yang perlu diberikan penekanan iaitu merancang idea agar ianya akan melancarkan lagi proses komunikasi yang akan berlaku. Merancang idea ini boleh dilakukan melalui perbincangan dengan kumpulan pengurusan tertinggi agar idea yang merangkumi semua aspek atau peringkat organisasi dapat disampaikan dengan jelas tanpa menimbulkan kesangsian dan kecelaruan serta konflik dalam kalangan subordinat yang akan menerima arahan itu.

\section{Analisis Keadaan Pendengar}

Adalah perlu bagi seorang pemimpin untuk menganalisis pendengar (audien) sebelum menyampaikan mesejnya. Analisis boleh dilakukan berdasarkan (a) 
siapa pendengar, (b) kedudukan pangkat, (c) kelulusan akademik, (d) latar belakang pekerjaan, (e) bilangan pendengar, dan (f) tempat.

Analisis seumpama ini penting untuk menghindari suasana yang tidak ceria dan tidak harmonis. Dengan adanya analisis seperti ini akan menimbulkan keseronokan dalam kalangan si pendengar dan mesej akan dapat disampaikan dengan lebih berkesan. Bersesuaian dengan hadis nabi SAW:

$$
\text { أمرنا أن نكلّم الثّاس على قدر عقوله }
$$

"Berbicaralah dengan menurut dengan kadar kemampuan akal mereka...” 27

\section{Isi Bicara Hendaklah Benar}

Seorang pemimpin hendaklah memastikan isi ucapan yang akan disampaikan adalah merupakan perkara-perkara yang benar. Islam mewajibkan umatnya khasnya para pemimpin untuk berkata benar dan tidak melakukan pembohongan dalam kepimpinannya seperti yang ditegaskan dalam al-Quran:

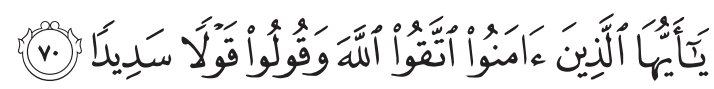

"Wahai orang-orang yang beriman, bertaqwalah kamu kepada Allah dan berkatalah dengan kata-kata yang benar..."

(Surah al-Aḥzāb, 33: 70)

\section{Gaya Bahasa hendaklah Bersesuaian}

Cara komunikasi yang baik ialah yang memberi penekanan kepada gaya bahasa mengikut suasana persekitaran yang ada. Firman Allah SWT dalam al-Quran:

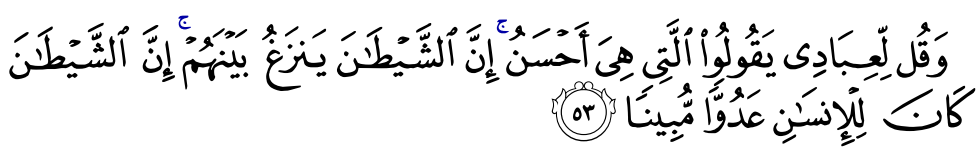

"Dan katakanlah (Wahai Muhammad) kepada hamba-hambaku yang beriman supaya mereka berkata dengan kata-kata yang baik. Sesungguh syaitan itu senantiasa menghasut di antara yang beriman dan yang menentang. Sesungguhnya syaitan merupakan musuh yang nyata kepada manusia "

(Surah al-Isrā', 17: 53)

27 al-Sakhawī, al-Maqāṣid al-Hasanah fì ma Ashtahar 'ala al-Alsinah, vol. 1 (Beirūt: Dār al-Kitāb al-'Arabī, 1985), no. hadis 177. 


\section{Nada Percakapan perlu Dikawal dan Sesuai}

Pemimpin apabila mereka berkomunikasi hendaklah menjaga dan mengawal antonasi suara. Kalau diperhatikan bagaimana sifat seorang khatib Jumaat yang baik dapat menyampaikan khutbahnya mengikut suasana para hadirin yang berada di hadapan. Ini bertujuan untuk menarik perhatian dan menghilangkan kebosanan mereka. Firman Allah SWT:

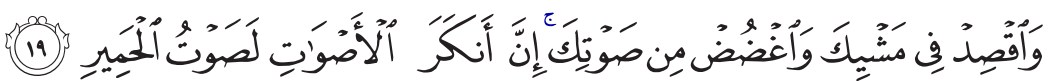

"Dan sederhanakanlah langkah mu ketika berjalan dan rendahkanlah suaramu. Sesungguhnya seburuk-buruk suara ialah suara keldai..."

(Surah Luqmān, 31: 19)

\section{Susunan Maklumat Perlu Jelas}

Ianya diperlukan agar si pendengar dapat memahami maklumat yang disampaikan dan tidak menimbulkan pertanyaan dan persoalan yang rumit apabila melaksanakan tugasan yang diberikan. Firman Allah SWT:

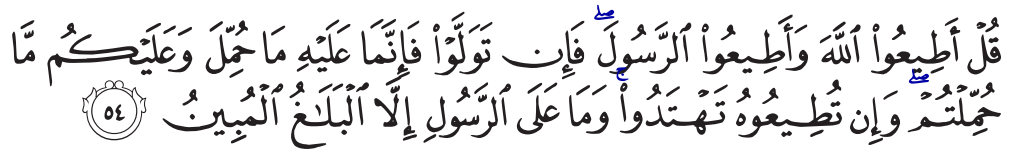

"Katakanlah lagi kepada mereka. Taatlah kamu kepada Allah dan taatlah kamu kepada Rasullah. Kemudian jika kamu berpaling ingkar maka ketahuilah sesungguhnya Rasulullah bertanggungjawab apa yang ditugaskan kepadanya. Dan jika kamu taat kepadanya nescaya kamu beroleh hidayah dan petunjuk. Dan sebenarnya Rasulullah bertanggungjawab menyampaikan perintah-perintah Allah dengan penjelasan yang terang dan nyata."

(Surah al-Nūr, 24: 54)

\section{Bahasa Badan Perlu Menyokong Lisan}

Ini dijelaskan dalam hadis Rasulullah SAW:

$$
\text { وسول الله ان هده رسول الله موعظة نرفت من مود العيون ووجلت منه القلوب قفلنا يا }
$$


"Apabila Rasulullah SAW berkhutbah, kedua-dua matanya merah, suaranya lantang (nyaring) dan semangatnya bangkit bagai seorang panglima perang yang memperingatkan tentang kedatangan musuh yang ingin memerangi umat Islam di ketika pagi atau petangnya... " 28

\section{Meninggalkan Celaan dan Umpatan}

Pemimpin yang berkesan ialah pemimpin tidak mengeji dan mengumpat subordinat mereka sendiri. Firman Allah SWT:

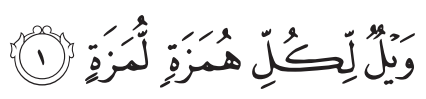

"Kecelakaan besar bagi setiap pengumpat dan pencaci..."

(Surah al-Humazah, 104: 1)

\section{Mendengar dengan Berkesan}

Seorang pemimpin mestilah menguasai kemahiran mendengar mesej yang disampaikan oleh subordinat. Ini memudahkannya untuk mengambil tindakan hasil maklumat yang diterimanya.

\section{DEFINISI KOMUNIKASI BERKESAN}

Komunikasi berkesan penting kerana tugas seorang pemimpin sentiasa berkait dengan percambahan, penciptaan hubungan dan penggunaan mekanisme tertentu yang banyak melibatkan aktiviti komunikasi dan komponennya. Komunikasi yang baik perlu untuk menjamin semua proses berjalan dengan baik supaya ianya memberi kesan kepada organisasi.

Mengikut Jaafar Muhamad, ${ }^{29}$ dalam memberikan takrifan yang mudah ianya sebagai satu proses interaksi antara penerima dan pemberi maklumat agar kedua-dua pihak saling memahami maksud yang ingin disampaikan. Manakala Hisham al-Thalib ${ }^{30}$ berpendapat bahawa komunikasi ialah membiarkan orang

28 Ibn Mājah, Sunan Ibn Mājah, vol. 1 (Beirūt, Lubnan: Dār al-Ma'rifah, 1996), no. hadis $2 / 43,14$.

29 Jaafar Muhamad, Pengantar Pengurusan (Petaling Jaya: Leeds Publication, 2004), 369.

30 Hisham al-Talib, Panduan Latihan bagi Petugas Islam (Kuala Lumpur: Nurin Enterprise, 1992), 182. 
lain mengenali anda dan menjalankan persefahaman dengan anda. Proses ini melibatkan perkongsian idea-idea, perasaan dan fikiran dari seseorang individu yang secara jujur.

Manakala komunikasi menurut al-Quran berdasarkan dari kata kerja "Ittsala" 31 yang bermaksud seru dan sampaikan sepertimana firman Allah SWT:

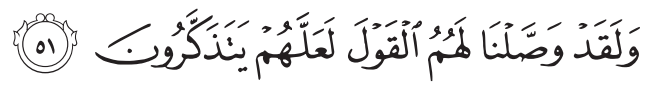

"Sesungguhnya Kami sampaikan kata-kata kepada mereka supaya mereka beroleh peringatan lalu beriman..."

(Surah al-Qașaṣ, ayat 51)

Terdapat ayat-ayat dalam al-Quran yang menerangkan maksud komunikasi seperti:

a) "Katakanlah"

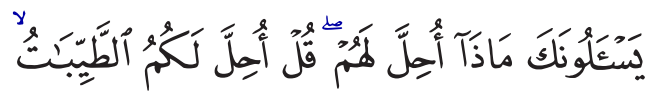

"Mereka bertanya kamu (wahai Muhammad) " Apakah perkara yang dihalalkan untuk mereka katakanlah (kepada mereka)

Dihalalkan untuk apa-apa sahaja makanan yang baik-baik...'

(Surah al-Mā'idah, 5: 4)

b) "Bacalah"

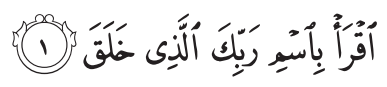

"Bacalah dengan nama tuhanMu yang telah menciptakan"

(Surah al-'Alaq, 96: 1)

c) "Khabarkanlah"

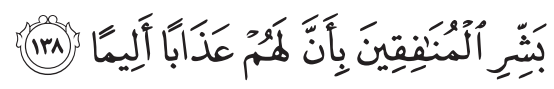

"Khabarkanlah kepada orang-orang munafiq sesungguhnya bagi mereka itu azab yang pedih."

(Surah al-Nisā', 4: 138)

\footnotetext{
31 Ibrāhim Muștafā, Mu 'jam al-Wasīṭ (Istanbul: Dār Da‘wah, 1989), 1037.
} 
d) "Berpesan-pesan"

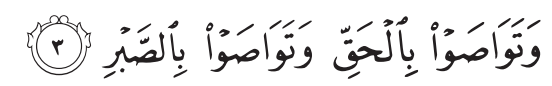

"Berpesan-pesan dengan kebenaran dan berpesan-pesan dengan kesabaran”

(Surah al-‘Așr, 103: 3)

\section{CIRI-CIRI KOMUNIKASI BERKESAN}

Terdapat beberapa ciri-ciri komunikasi sebagai asas kepada komunikasi berkesan. Antaranya:

a) Kefahaman; Iaitu para pendengar benar-benar memahami maksud yang dikehendaki. Sebaliknya, kalau mereka tidak memahami apa yang sedang diperkatakan bererti ianya bukan komunikasi yang berkesan.

b) Keseronokan; Kadang-kadang semasa kita sedang berkomunikasi, ianya tidak membawa satu maksud yang khusus. Bahkan semata-semata mencari keseronokan. Apabila kita seronok dengan perbualan kita, kita juga akan berasa seronok dan mesra dengan rakan bual kita. Perbualan yang menyeronokkan juga merupakan ciri-ciri komunikasi yang berkesan. Contohnya, perbualan di kedai-kedai kopi, di kantin pejabat, meja majlis perkahwinan dan kenduri-kendara.

c) Pengaruh kepada sikap; Ciri-ciri komunikasi yang berkesan juga mempunyai pengaruh kepada sikap si pendengar, nilai dan kepercayaan orang lain terhadap kita. Tujuan utamanya ialah menyampaikan maklumat dan dan berharap ada perubahan kepada si penerima. Biasanya dalam mesyuarat, taklimat, perbincangan, rundingan dan sebagainya. Di sana, kita cuba mengubah orang lain dengan cara mereka menerima pendapat kita. Apabila mereka menerima mesej yang disampaikan dengan terang dan jelas, pastinya tindakbalas yang diterima akan lebih mudah dan meningkatkan kualiti dan produktiviti.

\section{PANDANGAN IMAM AL-GHAZZALĪ MENGENAI KOMUNIKASI BERKESAN}

Imam al-Ghazālī dengan jelas menyatakan adab-adab mendengar yang perlu diberikan penekanan. Ini kerana tujuan mendengar itu ialah memahami setiap isi percakapan. Ini bermaksud setiap pendakwah perlu mempunyai 
kemahiran mendengar. Apabila ianya telah mendengar dan memahami apa yang diperkatakan akan melahirkan suatu perasaan dalam hati sanubarinya yang akan menggerakkan anggota badan untuk melaksanakan sesuatu tugas dan tanggungjawab. ${ }^{32}$ Ini menunjukkan bahawa peranan hati yang cukup patuh kepada pendengaran yang diterimanya.

Sekiranya apa yang didengarinya, mempunyai nilai positif ia akan menghasilkan manfaat yang baik dan begitu juga sebaliknya. Seseorang yang ingin berkomunikasi dengan baik, sewajarnya menguasai kemahiran mendengar seperti mana yang telah dijelaskan. Oleh itu, setiap pengurus dan pentadbir sewajarnya menguasai teknik berkomunikasi yang berkesan untuk menarik kakitangan untuk terus memberikan perhatian dan tumpuan terhadap perkara yang sedang disampaikan. Sekiranya komunikasi ini berlaku, ianya akan memberi kesan iaitu berlaku perubahan tingkahlaku dan sikap yang positif. Ini akan memberikan sumbangan ke arah kemajuan sesuatu organisasi.

\section{PENDAPAT IMAM AL-GHAZZĀLI MENGENAI DAKWAH (AMAR $\left.M A^{\prime} \boldsymbol{R} \bar{U} F \boldsymbol{N A H \overline { I }} M U N K A R\right)$}

Islam mengajar umatnya melaksanakan tuntutan amal makruf nahi mungkar sebagai suatu unsur kebaikan dalam pengurusan yang perlu dipupuk serta disemai. Manakala, sebarang unsur yang tercela seperti rasuah, penindasan, pecah amanah, khianat, pemerasan dan sebagainya pula perlu dicegah dan dibanteras habis-habisan secara bersungguh-sungguh. Kewajipan amar ma'rūf nahì munkar perlu difahami oleh setiap anggota dalam masyarakat dan organisasi. Slogan memerangi rasuah secara global yang dilancarkan oleh kerajaan perlu disambut baik, disokong dan dibantu oleh semua agensi dan pentadbiran. Agenda itu tidak mungkin akan berjaya jika tiada penglibatan bersungguh-sungguh dari semua pemimpin atasan dan bawahan. Sekiranya tiada yang melaksanakan tanggungjawab ini, ianya akan membawa kebinasaan kepada organisasi itu sendiri dan ini dilarang dalam Islam.

Firman Allah SWT dalam konsep amar ma'rūf nahī munkar dalam alQuran:

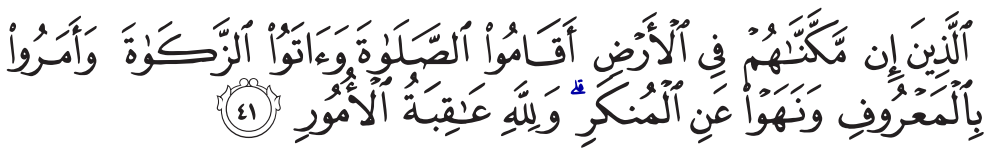

"Iaitu mereka (umat Islam) yang jika Kami berikan mereka kekuasaan memerintah di bumi nescaya mereka mendirikan

32 'Abd al-Salām Hārūn, Tahdhīb Ihyā' 'Ulūm al-Dīn li al-Imām al-Ghazālī, vol. 1 (Beirūt: Maktabah al-Kutub al-Thaqāfah, 1988), 263. 
sembahyang serta memberi zakat, dan mereka menyuruh berbuat kebaikan serta melarang dari melakukan kejahatan dan perkara yang mungkar. Dan (ingatlah) bagi Allah jumlah kesudahan segala urusan..."

(Surah al-Hajj, 22: 41)

Imam al-Ghazālī telah menerangkan dengan jelas kewajipan seorang muslim apatah lagi sekiranya berada dalam saf kepimpinan untuk memastikan dirinya dan mereka yang berada di bawah kawalannya mengamalkan konsep amar ma'rūf nahī munkar dalam kehidupan seharian. Malah, ianya akan menentukan jatuh dan bangunnya sesebuah ummah (organisasi). Firman Allah SWT dalam al-Quran:

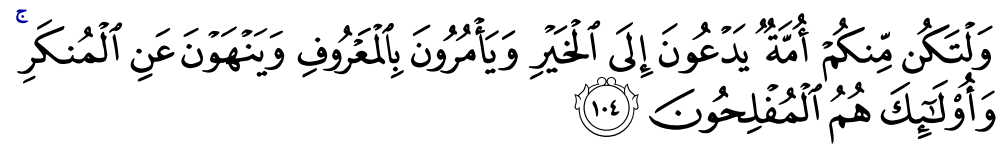

"Dan hendaklah ada dalam kalangan kamu satu golongan yang menyeru ke arah kebaikan dan menyuruh perbuatan makruf dan mencegah kemungkaran dan itulah mereka golongan yang berjaya..."

(Surah Āli-'Imran, 3: 104)

Dalam ayat ini, terdapat tiga arahan penting untuk menjadikan sesuatu organisasi itu berjaya: ${ }^{33}$

1. Mengajak (berdakwah) ke arah melakukan kebaikan.

2. Menyuruh kepada makruf (arahan)

3. Mencegah kemungkaran (larangan)

Arahan ini ditujukan juga kepada sekelompok manusia sebagai fardu kifāyah iaitu mereka yang mempunyai kuasa (kepimpinan) dalam sesebuah organisasi. Kesan tindakan pihak atasan yang melakukan tiga elemen tersebut akan menjadikan organisasi bertambah mantap. Kadang-kadang ada juga yang berpendapat bahawa sikap negatif pada seseorang tidak akan menjejaskan perjalanan sesebuah organisasi atau memberi kesan yang buruk. Tanggapan ini tidak benar sama sekali.

Diriwayatkan dari Saidina Abu Bakar al-Siddiq RA dalam khutbahnya telah menyatakan: ${ }^{34}$

33 'Abd al-Salām Hārūn, Tahdhīb Ihyā' 'Ulūm al-Dīn li al-Imām al-Ghazāà̄, vol. 1, 285.

34 'Abd al-Salām Hārūn, Tahdhīb Ihyāa' 'Ulūm al-Dīn li al-Imām al-Ghazāà̄, vol. 1, 286. 
"Wahai manusia! Sesungguhnya kamu telah membaca ayat ini dan mentakwil yang sebaliknya iaitu firman Allah dalam surah al-Maidah ayat (105) yang berbunyi:

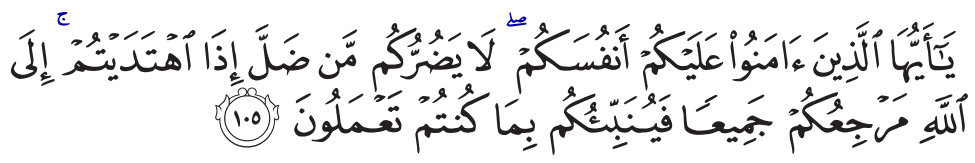

"Wahai orang-orang yang beriman, jagalah diri kamu dari melakukan sesuatu yang dilarang oleh Allah. Orang-orang yang sesat tidak akan mendatangkan kepada kemudharatan apabila kamu sendiri mendapat hidayah."

"Sedangkan aku sendiri mendengar dari Rasulullah sendiri yang menyatakan:

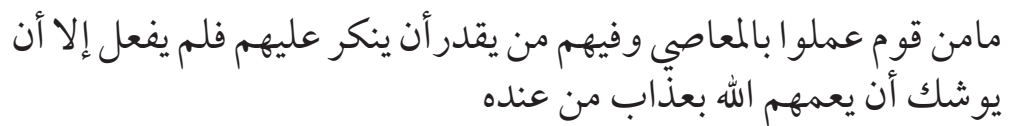

"Mana-mana golongan yang melakukan maksiat sedangkan ada dalam kalangan mereka yang mampu mencegah perbuatan maksiat dalam kalangan mereka tetapi mereka tidak melakukannya melainkan Allah akan timpakan ke atas mereka kesemuanya azab."

Jelas di sini bahawa semua pihak berperanan memastikan organisasi mereka hendaklah dijauhkan dari unsur-unsur yang boleh menghancurkan keutuhan sesebuah organisasi. Di sini, seorang pemimpin organisasi hendaklah memainkan peranan cuba berkomunikasi dengan kakitangan melalui pelbagai medium atau keadaan untuk memastikan segala mesej yang hendak disampaikan difahami dan membolehkan kakitangannya melakukan perubahan sikap dan tingkah laku ke arah yang lebih baik. Keutuhan sesebuah organisasi bergantung kepada corak kepimpinan yang menjadi tunjang dan nadinya.

\section{RUKUN-RUKUN AMAR MA'R $\bar{U} F$ NAHI MUNKAR (HISBAH)}

Sepertimana ibadat khusus yang lain, amar ma'rūf nahī munkar juga mempunyai rukun-rukunnya dan Imam al-Ghazālī menjelaskan terdapat beberapa rukun dalam sistem hisbah. ${ }^{35}$ Antaranya:

35 'Abd al-Salām Hārūn, Tahdhīb Ihyā' 'Ulūm al-Dīn li al-Imām al-Ghazālī, vol. 1, 287. 


\section{1. al-Muḥtasib (Pelaksana Hisbah)}

Pelaksana hisbah mestilah terdiri seorang yang mukallaf, Islam dan mempunyai kuasa (autoriti) iaitu yang dilantik oleh pemerintah atau badan yang diberi mandat. Walaupun ada pendapat yang tidak mensyaratkan ada keizinan dari pihak berkuasa untuk melakukan pencegahan. ${ }^{36}$ Ini dari sudut yang umum. Tetapi dalam berorganisasi, sudah tentu kemungkaran dalam pentadbiran mestilah melalui kuasa yang ada. Hal seperti ini adalah perlu untuk mengelakkan salah faham yang ketara dikalangan anggota organisasi.

\section{Ma fìhi al-Hisbah (Perkara Mungkar)}

Perkara mungkar ialah sesuatu perbuatan yang dilarang oleh syarak dan ianya memang berlaku semasa dilaksanakan hisbah ke atasnya. Termasuk dalam kategori ini juga ialah perkara-perkara yang melanggar etika kerja dan displin organisasi. Menjadi syarat perkara kemungkaran yang dilakukan tidak dibongkar sekiranya ia berlaku di dalam rumah atau permis persendirian. Ini dinyatakan dalam al-Quran:

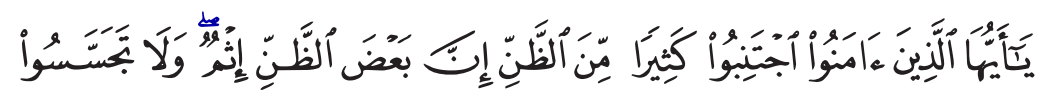

"Wahai orang yang beriman hendaklah kamu menjauhi dari sifat berburuk sangka dan jangan kamu sesekali mengintai-ngintai kesalahan orang lain"

(Surah al-Ḥujurāt, 49: 12)

Larangan ini jelas dan menjadi kewajipan setiap pentadbir agar menjaga adab-adab yang perlu dipatuhi. ${ }^{37}$ Diriwayat pernah Saidina 'Umar al-Khatțab memanjat sebuah rumah untuk melihat kemungkaran yang berlaku. Perbuatan ini telah ditegur oleh tuan rumah dengan mengatakan perbuatannya telah melanggar tiga adab-adab:

a) Mengintai sedangkan perbuatan ini telah dilarang oleh Allah SWT.

b) Tidak masuk melalui pintu sedangkan jelas dalam adab-adab Islam apabila memasuki sesebuah rumah hendaklah melalui pintunya bukan melalui tingkapnya.

c) Tidak meminta izin untuk masuk. Adapun kesalahan beliau hanya dari satu sudut sahaja.

36 Șāliḥ Shamī, al-Muhadhdhab min Ihyyā' 'Ulūm al-Dīn (Bayrūt: Dār Qalam, 1993), 470.

37 Șāliḥ Shamī, al-Muhadhdhab min Ihyyā' 'Ulūm al-Dīn, 471. 


\section{3. al-Muhtasab ‘alayh (Pelaku Kemungkaran)}

Pelaku mestilah seorang manusia iaitu kakitangan atau subordinat. Mereka yang tidak terlibat dalam organisasi tidak boleh untuk diambil tindakan disiplin ke atas mereka. Di sebut sebagai seorang kakitangan sudah sewajarnya seseorang yang sudah boleh dipertanggungjawabkan (mukallaf). Maka kelakuan atau tingkah laku yang bertentangan dengan etika dan disiplin boleh diberikan teguran dan tindakan yang boleh dikenakan ke atasnya sebagai satu peringatan atau satu bentuk denda.

\section{Nafs al-Iḥtisāb (Kaedah Perlaksanaan Hịisbah)}

Terdapat beberapa prosedur dan adab-adab yang perlu dijaga semasa hisbah dijalankan antaranya menggunakan bahasa yang lunak dan lembut untuk memberitahu seseorang akan kesalahan yang dilakukan. Ini mungkin berlaku atas kejahilannya sendiri.

Seseorang muhtasib (ketua) sewajarnya memiliki ciri-ciri akhlak mahmudah (terpuji). Antaranya, ianya mestilah seorang berilmu dan serta mengetahui had dan batasan kuasa yang perlu dipatuhi semasa melaksanakan hisbah itu sendiri. Selain itu, seorang muhtasib hendaklah ada padanya sifat warak yang akan menjadi benteng pada diri dari perkara-perkara yang menyalahi syarak seperti rasuah, ponteng kerja dan sebagainya. Seorang muhtasib yang profesional boleh berlemah lembut dalam pertuturan dan sikapnya. Sekiranya berlaku keadaan seperti marah atau suasana yang tidak terkawal, contohnya di mana ilmu dan sifat warak sahaja tidak memadai untuk menangani situasi tersebut. Ketika ini, sifat lemah lembut yang ditonjolkan boleh menjadikan seseorang yang sedang marah menjadi reda $^{38}$ dan boleh menerima teguran dengan berlapang dada. Langkah seumpama ini perlu untuk mengimbangi suasana yang berlaku ketika itu.

\section{TAHAP-TAHAP MENCEGAH KEMUNGKARAN}

Islam sebagai satu agama yang mempunyai disiplin yang tegas tetapi lunak dalam mengajak manusia ke arah kebaikan dan mencegah kemungkaran. Dalam Kitab Maw'izah al-Mu'minin menjelaskan tatacara atau tahap yang perlu dipatuhi semasa melaksanakan amar ma'rūf nahī munkar. Antara yang perlu dipatuhi ialah: ${ }^{39}$

38 Șāliḥ Shamī, al-Muhadhdhab min Ihyā' 'Ulūm al-Dīn, 294.

39 Jamāl al-Dīn al-Qāsimī, Maw 'iẓah Mu'minīn min Ihyyà' 'Ulūm al-Dīn (Bayrūt: Dār al-Ma'rifah, 1903), 173. 
a) Memaklumkan kepada si pelaku kesalahan mengenai kemungkaran yang dilakukan terlebih dahulu tanpa mencercanya. Barangkali dia melakukan kesalahan atas kejahilannya sendiri. Oleh kerana proses ini akan membuka keaiban mereka dan mengguris hati mereka, sewajarnya dilakukan dengan penuh lemah lembut dan lunak. Seperti dikatakan seseorang itu tidak dilahirkan terus menjadi serba tahu, maka hendaklah diberitahu terlebih dahulu dan seharusnya diketahui bahawa menyakiti hati seseorang adalah dilarang. Cara seumpama ini akan membuka hati subordinat agar kesalahan yang sama tidak diulangi lagi pada masa akan datang. Dengan cara sumpama ini, sekurang-kurangnya akan dapat mengingatkan kepada mereka agar tidak mengulangi dengan kesalahan yang sama pada masa akan datang. Adalah lebih baik sekiranya setiap kesilapan diberikan memo peringatan secara hitam putih di mana ianya akan dicatatkan setiap tindakan telah diambil mengikut peruntukan kuasa yang ada.

b) Melarang dengan menasihati serta memberi amaran-amaran keras. Tahap ini sesuai untuk mereka yang mengetahui dan menyedari kesalahan yang mereka lakukan seperti kaki minum arak, si perampas harta benda orang ramai. Ketika itu, hendaklah diberikan nasihat yang berupa peringatan dan memberikan amaran-amaran Allah SWT yang menakutkan berkaitan kesalahan mereka serta riwayat-riwayat para salaf al-ṣälih dan golongan yang bertaqwa. Cara penyampaian hendaklah dilakukan dengan cara yang lembut bukan cara yang kasar serta boleh menjauhkan mereka dari Islam. Para pentadbir dan pengurus sememangnya menguasai teknik psikologi untuk berhadapan dengan kakitangan yang bermasalah. Tindakan disiplin yang dikenakan ke atas mereka hendak setimpal dengan perbuatan yang dilakukan. Firman Allah SWT:

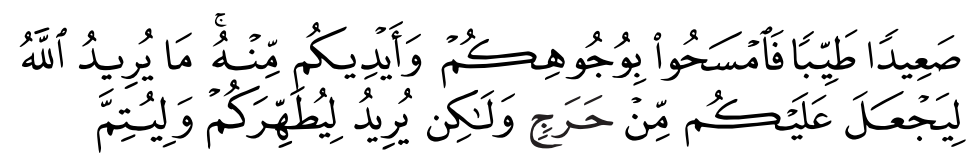

"Sesungguhnya Allah menyuruh agar berlaku adil dan belas kasihan, memberikan bantuan kepada kaum kerabat yang terdekat, mencegah perbuatan keji, mungkar dan perbuatan yang melampaui batas (kederhakaan). Dia yang mengajarkan kamu semua itu dengan dengan perkara-perkara tadi agar kamu semua mengerti."

(Surah al-Naḥl, 16: 90)

c) Menggunakan teguran keras ketika saluran dan cara yang lembut tidak memberikan kesan atau si pelaku mengulangi kesalahan yang sama atau 
bersikap mempermainkan nasihat-nasihat yang diberikan. Ini bertepatan dengan apa yang ditegaskan oleh Allah SWT dalam al-Quran:

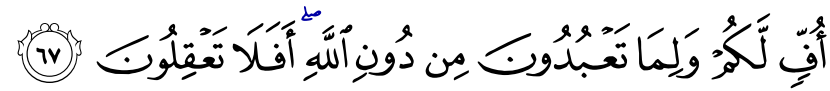

"Jijik perasaanku terhadap kamu dan apa yang kamu sembah selain dari Allah! Maka kenapa kamu tidak menggunakan akal fikiran kamu"

(Surah al-Anbiyā', 21: 67)

Walaupun begitu ia hendaklah melalui dua adab yang perlu dilakukan: ${ }^{40}$

a) Menggunakan cara yang keras ketika darurat sahaja dan ketika mana cara yang lembut tidak dapat mengengkang perbuatan kemungkaran atau salahlaku yang dilakukan. Darurat yang dimaksudkan ialah darurat yang boleh merosakkan perjalanan organisasi yang dipimpin. Seorang pemimpin yang cekap seharusnya mempunyai kemahiran untuk membaca, menilai, dan mengenalpasti masalah organisasi yang timbul dan mempunyai pilihan cara-cara untuk mengatasinya. Kelemahan membaca masalah akan membawa kepada kesilapan pembetulan dan pemulihan semula organisasi yang dipimpinnya.

b) Berkata-kata dengan kebenaran serta tidak memanjangkan kata-kata bahkan memfokuskan kepada perkara-perkara yang berkaitan dan relevan sahaja mengikut keperluan.

c) Mengubah kemungkaran dengan kuasa yang ada. Kuasa ini merujuk kepada kuasa pemerintahan (kerajaan). Tidak seharusnya seseorang individu mengambil tindakan sendiri dalam pencegahan kemungkaran yang berlaku. Seandainya dibiarkan berlaku, ianya akan menghuru-harakan keadaan dan tidak akan mencapai maksud dakwah itu sendiri. Penguatkuasaan undang-undang hanya boleh dilaksanakan sekiranya mempunyai kuasa sah yang diiktiraf oleh pihak berkuasa dalam masyarakat. Apa yang boleh disarankan ialah penggunaan kata-kata atau yang disebutkan sebagai komunikasi berkesan yang akan dapat merubah tingkah laku seseorang. Pentadbir atau yang dikatakan sebagai pendakwah dalam organisasi yang mempunyai kemahiran berkomunikasi adalah seorang yang berjaya dalam tugasnya. Dengannya dapat menarik masyarakat untuk melaksanakan kewajipan dengan sebaik-baiknya. Faktor kebijaksanaan setiap pemimpin organisasi pastinya mempengaruhi perjalanan pentadbiran organisasi. Malah seorang ketua yang memahami kewajipan amar ma 'rūf nahī munkar

40 Jamāl al-Dīn al-Qāsimī, Maw 'iẓah Mu'minīn min Ihyyā' 'Ulūm al-Dīn, 173. 
dalam organisasinya akan melaksanakannya dengan rasa penuh kesedaran dan rasa bertanggungjawab.

Dalam suatu kisah digambarkan secara psikologi bagaimana Rasulullah mencegah kemungkaran yang berlaku. Seorang pemuda yang meminta kebenaran daripada Nabi untuk berzina. Walaupun para sahabat marah dengan permintaan pemuda itu tetapi Rasulullah berjaya menghindarkan perbuatan maksiat dengan memberikan analogi yang mudah diterima oleh pemuda itu. Ditanya sekiranya perbuatan zina berlaku ke atas keluarga pemuda adakah dia mahu menerimanya? Maka, pemuda itupun enggan meneruskan hasratnya. ${ }^{41}$ Pendekatan seumpama ini perlu ada pada seorang pentadbir atau pemimpin iaitu cuba membaca isihati mereka yang berada di bawah kawalannya. Dengan sedikit nasihat, maka satu kemungkaran dapat dielakkan. Kaedah ini sewajarnya dipraktikkan oleh para pentadbir atau pemimpin dalam menangani masalah disiplin yang timbul.

\section{KESIMPULAN}

Bidang komunikasi memainkan peranan yang begitu penting dalam aktiviti seharian manusia seperti bercakap, mendengar, menonton, membaca, menulis, berdoa dan sebagainya. Islam sebagai suatu cara hidup yang sempurna dan lengkap sudah pastinya mempunyai dasar dan prinsip supaya ianya selaras mengikut roh Islam itu sendiri.

Antara sifat-sifat komunikasi yang baik ialah:

a) Memberi peluang kepada subordinat peluang bercakap dan mengeluarkan pendapat mereka. Peluang bercakap dan menyuarakan pendapat merupakan salah satu cara untuk pihak pengurusan atasan membaca dan mengenal pasti masalah yang dihadapi oleh pihak subordinat

b) Memberi maklumat perjalanan organisasi atau perkara-perkara yang berkaitan yang memberi manfaat kepada subordinat. Subordinat perlu mengetahui perjalanan dan struktur pentadbiran atasan untuk memudahkan mereka menyalurkan maklumat.

c) Memberikan penjelasan sekiranya berlaku konflik dalam kalangan subordinat. Pertemuan antara pihak-pihak yang berkonflik boleh memberikan jalan dan ruang untuk menyelesaikan masalah yang timbul. Persetujuan bersama boleh dicapai setelah perbincangan dilakukan.

${ }_{41}$ Șālih Shamī, al-Muhadhdhab min Ihyā' 'Ulūm al-Dīn, 475. 
d) Menimbang dan menyelidiki maklumat yang diterima agar ianya tidak menimbulkan fitnah dan masalah kepada organisasi kemudian hari nanti. Pengurus yang cekap sewajarnya memastikan maklumat yang diterima dan yang hendak disampaikan adalah maklumat yang benar sah dan betul sahaja. Ini untuk mengelakkan salah yang timbul akibat kekeliruan yang timbul.

Secara ringkasnya, ciri-ciri komunikasi berkesan dapat dirumuskan seperti kefahaman, keseronokan dan pengaruh terhadap sikap. Komunikasi kepimpinan sememangnya amat penting untuk memastikan matlamat organsasi dapat dicapai melaluinya di samping berupaya mewujudkan perubahan yang positif dalam sesebuah organisasi. Kepimpinan komunikasi yang berkesan ialah mereka yang berupaya menjalankan tugas formal pemimpin seperti mengeluarkan arahan, memberi penjelasan, tunjuk ajar, memberi nasihat, mempengerusikan mesyuarat dan menyelia tugas kakitangan bawahan. Seorang pemimpin sewajarnya menguasai teknik-teknik komunikasi yang berkesan untuk mengelakkan berlaku konflik dalam kalangan subordinat.

\section{RUJUKAN}

'Abd al-Salām Hārūn, Tahdhīb Ihyā' 'Ulūm al-Dīn li al-Imām al-Ghazālì, vol. 1 (Bayrūt: Maktabah al-Kutub al-Thaqāfah, 1988).

Abdul Mua'ti Zamri Ahmad, Santun Komunikasi (Kuala Lumpur: Dewan Bahasa dan Pustaka, 2001).

Ab̄̄ Fidā' Ismā'il bin Kathīr al-Qurayshī al-Dimashq, Tafsīr al-Qur'ān al'Azìm, vol. 3 (Bayrūt: Dār al-Andalus, 1984).

Ahmad Muștiaā al-Marāghī, Tafsīr al-Marāghī, vol. 4 (Bayrūt: Dār Ihyā’ alTurāth al-'Arab, 1974).

Asep Dadan Wildan, Prinsip-Prinsip Komunikasi di dalam Islam: Tumpuan terhadap Surah al-Hujurat (Kuala Lumpur: Universiti Malaya, 2003).

Ghazzali Darusalam, Dinamika Ilmu Dakwah Islamiah (Kuala Lumpur: Utusan Publication, 1996).

Hisham Al-Talib, Panduan Latihan bagi Petugas Islam (Kuala Lumpur: Nurin Enterprise, 1992).

Ibrāhim Muștafā, Mu 'jam al-Wasịt (Istanbul: Dār al-Da'wah, 1989).

Jaafar Muhamad, Pengantar Pengurusan (Petaling Jaya: Leeds Publication, 2004).

Jamāl al-Dīn al-Qāsimī, Maw 'izah Mu'minīn min Ihyā' 'Ulūm al-Dīn (Bayrūt: Dār al-Ma'rifah, 1903). 
Kamaruzzaman Noordin, Komunikasi Kepimpinan Menurut Islam dalam Dimensi Pengurusan Islam (Kuala Lumpur: Penerbit Universiti Malaya, 2006).

Kamus Dewan, edisi ke-3 (Kuala Lumpur: Dewan Bahasa dan Pustaka, 1996). al-Mawardī, al-Aḥkām al-Sulțāniyyah (Bayrūt: Dār al-Kutub 'Ilmiyyah, 1985). Mohd Yusuf Husin, Kecemerlangan Pentadbiran Dasar dan Amalan dalam Islam (Kuala Lumpur: Institut Tadbiran Awam Negara, 1991).

Mohd Yusuf Hussain, 'Komunikasi Kepimpinan Menurut Perpekstif Islam,' dalam Kecemerlangan Pentadbiran dan Amalan dalam Islam, ed. Shafie Mohd Salleh et al. (Kuala Lumpur: Institut Tadbiran Awam Negara, 1990).

Muhd Mansur Abdullah, Komunikasi dalam Pengurusan (Kuala Lumpur: Dewan Bahasa dan Pustaka, 2002).

Muḥammad bin 'Isa al-Tirmidhī, Jāmi ' al-Tìmidhì (Bayrūt: Dār al-Gharb alIslāmī, 1998), no. hadis 2643.

Muḥammad Sa‘īd Ramaḍān al-Būṭị, Sìrah al-Nabawiyyah (Sūriyyah: Dār alFikr, 1991).

Onong Uchana Effendy MA, Kepimpinan dan Komunikasi (Bandung: Penerbit Alumni, 1981).

Raja Roslan Raja Abd. Rahman, Azizi Yahya \& Mohd. Salleh Hassan, 'Peranan Komunikasi Kepimpinan Diri dan Organisasi dalam Perspektif Islam,' (Seminar Kebangsaan Kemahiran Insaniah dan Kesejahteraan Sosial, Mahkota Hotel Melaka, 18-19 Ogos 2008).

al-Sakhawī, al-Maqāșid al-Hasanah fì ma Ashtahar 'ala al-Alsinah, vol. 1 (Bayrūt: Dār al-Kitāb al-'Arabī, 1985), no. hadis 180.

Saodah Wok, Teori-Teori Komunikasi (Kuala Lumpur: PTS Publishing Sdn. Bhd., 2006).

Șāliḥ Shamī, al-Muhadhdhab min Ihyyà' 'Ulūm al-Dīn (Bayrūt: Dār Qalam, 1993). 